\title{
Could contaminant induced mutations lead to a genetic diversity overestimation?
}

\author{
Olímpia Sobral • Maria Aparecida Marin-Morales • \\ Rui Ribeiro
}

Accepted: 30 April 2013/Published online: 18 May 2013

(C) Springer Science+Business Media New York 2013

\begin{abstract}
Contaminant driven genetic erosion reported through the inspection of selectable traits can be underestimated using neutral markers. This divergence was previously reported in the aquatic system of an abandoned pyrite mine. The most sensitive genotypes of the microcrustacean cladoceran Daphnia longispina were found to be lacking in the impacted reservoir near the entrance of the metal rich acid mine drainage (AMD). Since that divergence could be, at least partially, accounted for by mutagenicity and genotoxicity of the AMD, the present study aimed at providing such a characterization. The Allium cepa chromosomal aberration assay, using root meristematic cells, was carried out, by exposing seeds to $100,10,1$, and $0.1 \%$ of the local AMD. Chromosomal aberrations, cell division phases and cell death were quantified after the AMD exposure and after 24 and $48 \mathrm{~h}$ recovery periods. The AMD revealed to be mutagenic and genotoxic, even after diluting it to 1 and $0.1 \%$. Dilutions within this range were previously found to be below the lethality threshold and to elicit sublethal effects on reproduction of locally collected $D$. longispina clonal lineages Significant mutagenic effects (micronuclei and chromosomal breaks) were also found at $0.1 \%$ AMD, supporting that exposure may induce permanent genetic alterations.
\end{abstract}

O. Sobral · R. Ribeiro $(\bowtie)$

Department of Life Sciences, IMAR-Instituto do Mar, University of Coimbra, Apartado, 3046, 3001-401 Coimbra, Portugal

e-mail: rui.ribeiro@zoo.uc.pt

M. A. Marin-Morales

Departamento de Biologia, Instituto de Biociências de Rio Claro,

Universidade Estadual Paulista Júlio de Mesquita Filho,

SP, Brazil
Recovery tests showed that AMD genotoxic effects persisted after the exposure.

Keywords Chromosomal aberrations - Micronuclei · Allium cepa $\cdot$ Acid mine drainage $\cdot$ Recovery

\section{Introduction}

The loss of genetic diversity by contaminant driven directional selection has been reported through the inspection of adequate selectable traits (Ribeiro and Lopes 2013). In large populations, where genetic drift is negligible, this loss would be undetected through the use of neutral markers, which are suited to evaluate microevolutionary events other than directional selection (Pfrender et al. 2000; Ribeiro and Lopes 2013). Furthermore, if contaminant induced mutations occur then genetic diversity could be increased and/or overestimated. Ribeiro et al. (2012) reviewed a case-study of contaminant driven genetic erosion of a zooplankton population-the crustacean cladoceran Daphnia longispina-impacted with a metal rich acid mine drainage (AMD), using tolerance to lethal levels of AMD and of copper as the selectable markers (Lopes et al. 2005; Agra et al. 2011). This genetic diversity loss was undetected using neutral markers, with some results pointing to the opposite direction (Martins et al. 2005, 2009; Silva et al. 2010). This could have been due to an ineffective genetic drift, possibly masked with the incursion of new alleles by gene flow, and/or by the increase of profiles diversity due to an increased mutation rate (Ribeiro et al. 2012). Therefore, the present study aimed at evaluating the mutagenicity and genotoxicity of that particular AMD effluent. The median effective dilution, using artificial pond water, of this AMD effluent on $D$. 
longispina reproduction was previously found to range between 0.1 and $1.1 \%$ (Saro et al. 2012). An exposure to a $3 \%$ dilution would reduce the population size down to at least $10 \%$, with a median survival time lower than $24 \mathrm{~h}$ (Lopes et al. 2005; Martins et al. 2007). Therefore, mutagenic effects of this AMD would only be relevant for microevolution of the population at the impacted site if occurring at percentages close to or lower than around $1 \%$.

Houk (1992) considered three classes of DNA damage: point mutations on DNA sequence, loss or gain of chromosome fragments (clastogenesis), and alterations on chromosome number by loss or gain of whole chromosomes (aneugenesis). Genotoxicity includes a wide range of effects such as lesions in the DNA strand, DNA adducts, sister chromatide exchange, additional DNA synthesis, and also effects on cellular components related with the cellular cycle, such as protein growth factors, spindle fibers and enzymes (e.g. topoisomerase) (Dearfield et al. 2002; Whysner et al. 2004). Repair mechanisms can recuperate temporary genotoxic effects, but mutagenic effects are persistent (Dearfield et al. 2002). With cytogenetic assays, it is possible to identify harmful effects of a stressor at different concentrations and exposure times (Au et al. 1990; Heddle et al. 1991; Ulsh et al. 2004; Pérez-Cadahía et al. 2008). There are hundreds of short-term cytogenetic assays, using a wide range of test organisms (from prokaryotic to mammal cells), which can be applied to study potential mutagenicity and genotoxicity. Assays with plants can be used to assess genotoxicity, providing accurate information and being easier than with animal cells or embryos (Fiskesjö 1985, 1993; Rank and Nielsen 1993; Grant 1994, 1998; Chauhan et al. 1999; Grant 1999; Patra and Sharma 2002; Ma et al. 2005; Leme and Marin-Morales 2009; Mazzeo et al. 2011). In the present study, the Allium cepa chromosomal aberration assay, using root meristematic cells, was carried out to evaluate the possibility of AMD induced mutations.

\section{Materials and methods}

Acid mine drainage

The AMD effluent was collected in the water system of a copper mine located in southern Portugal (São Domingos, $\left.37^{\prime} 37^{\circ} \mathrm{N}, 07^{\circ} 30^{\prime} \mathrm{W}\right)$. Even though being abandoned since 1967 , the effluent is highly acidic $(\mathrm{pH} \approx 2)$ and contaminated with metals (Table 1 ) as the result of continuous oxidation of mine tailings (Pereira et al. 1995; Lopes et al. 1999, 2000; De Bisthoven et al. 2004; Moreira-Santos et al. 2004; Gerhardt et al. 2005; Lopes et al. 2005; MoreiraSantos et al. 2008; Agra et al. 2010). No other sources of contamination are present in this system, neither agriculture and industrial activities nor urban runoff (Ribeiro et al. 2012).

Citotoxicity, mutagenicity and genotoxicity testing

Seeds of $A$. cepa ( $2 \mathrm{n}=16$ chromosomes) from a same strain and variety (baia periform) were used to evaluate genotoxic and mutagenic effects of the effluent. The AMD effluent was serially diluted with milli-Q water and 100 , $10,1,0.1$, and $0 \%$ AMD were tested, the latter being the negative control. Conductivity of AMD dilutions was 4780, 849,149 , and $18.9 \mu \mathrm{S} / \mathrm{cm}$, respectively, and $\mathrm{pH}$ was 1.8 , $2.3,2.9$, and 4.1 , respectively.

Metal concentrations were quantified by graphite furnace atomic absorption $(\mathrm{Cd}, \mathrm{Co}, \mathrm{Ni}$, and $\mathrm{Pb})$, by inductively coupled plasma atomic emission ( $\mathrm{Al}, \mathrm{Cu}, \mathrm{Fe}, \mathrm{Mn}$, and $\mathrm{Zn}$ ), and by hydride generation atomic absorption (As), in a certified laboratory (Instituto Superior Técnico, Lisbon, Portugal). Two positive controls were used: methyl methanesulfonate (MMS, CAS 66-27-3) at $4 \times 10^{-4} \mathrm{M}$, as a clastogenic agent, and trifluralin (2,6-dinitro-N,N-dipropyl4-trifluoro-methylaniline) (CAS 1582-09-8) at $0.84 \mathrm{ppm}$ as an aneugenic agent (Fernandes et al. 2007).

Onion seeds were germinated at $19-21^{\circ} \mathrm{C}$ in Petri plates, internally covered with filter paper wetted with the respective treatment. Four replicates per treatment, each one with 100 seeds were used. The test ended when roots from the negative control were $1-\mathrm{cm}$ long, which took 4-5 days. Then, a third of the germinated seeds was collected and fixed in Carnoy I (3:1 alcohol:acetic acid; v:v) from 6 to $24 \mathrm{~h}$. The remaining germinated seeds were transferred to other Petri plates wetted with milli-Q water. This recovery treatment was used to assess the conduct of the injured cells after some cycles of mitotic division. After 24 and $48 \mathrm{~h}$, one third of the seeds was fixed as described above. Fixed roots were hydrolyzed in $\mathrm{HCl} 1 \mathrm{~N}$, in a bath at $60{ }^{\circ} \mathrm{C}$ for $8-11 \mathrm{~min}$, stained with Schiff's reagent for $2 \mathrm{~h}$ in the dark, and then washed with distilled water. To prepare the slides, the meristematic regions were cut onto a slide into a drop of $2 \%$ acetic carmine solution to increase cytoplasm contrast, covered with a cover slip and carefully squashed. The cover slip was removed with liquid nitrogen and the slides mounted in synthetic resin (Enthellan ${ }^{\circledR}$, Merck) to further analysis.

At the end of the test, the germination index, in $\%$, was calculated as the proportion of seeds with visible radicle protrusion. Over 40 randomly picked roots from each treatment were measured. Ten slides of each treatment were observed at an optical microscope $(1000 \times)$ and a minimum of 500 intact cells per slide (5000 per treatment) were counted, distinguishing the number of cells in each stage of mitosis, interphase and cell death. Chromosome aberrations and micronuclei were recorded in all phases of 
Table 1 Metal concentrations in the tested dilutions of the acid mine drainage (AMD) used in the Allium cepa genotoxicity test

\begin{tabular}{|c|c|c|c|c|c|c|c|c|c|c|}
\hline \multicolumn{11}{|c|}{ Metal $\left(\mu \mathrm{gL}^{-1}\right)$} \\
\hline AMD & $\mathrm{Al}$ & $\mathrm{Fe}$ & $\mathrm{Cu}$ & $\mathrm{Mn}$ & $\mathrm{Zn}$ & $\mathrm{Co}$ & $\mathrm{Ni}$ & $\mathrm{Cd}$ & $\mathrm{Pb}$ & As \\
\hline $100 \%$ & $440 \times 10^{3}$ & $353 \times 10^{3}$ & $41 \times 10^{3}$ & $28 \times 10^{3}$ & $21 \times 10^{3}$ & $2.5 \times 10^{3}$ & 800 & 308 & 24 & 1.5 \\
\hline $10 \%$ & $46 \times 10^{3}$ & $33 \times 10^{3}$ & $4.0 \times 10^{3}$ & $2.9 \times 10^{3}$ & $2.1 \times 10^{3}$ & 250 & 72 & 7.3 & 3 & $<1.0$ \\
\hline $1 \%$ & $4.7 \times 10^{3}$ & $3.3 \times 10^{3}$ & 410 & 280 & 220 & 24 & 7 & $<1.0$ & $<3$ & $<1.0$ \\
\hline $0.10 \%$ & 450 & 300 & $<50$ & 28 & $<50$ & 3 & $<5$ & $<1.0$ & $<3$ & $<1.0$ \\
\hline
\end{tabular}

the cell cycle. Cytotoxic effects were analyzed by quantifying both mitotic cells and cells in death process. Cell death was identified by morphological alterations of the nucleus and/or cell (Kroemer et al. 2009). Mainly at the undiluted AMD, fragmented cells with loss of cellular and nuclear contents were observed, but these cells were not counted due to the difficulty of distinguishing cytotoxic effects (cell in death process) from technique effects (cell rupture during slide preparation). Despite the soft squash of the root tip being identical in all treatments, cells exposed to $100 \%$ AMD were less resistant. Dead cells were those showing vacuolated and swollen cytoplasm or heteropycnotic, condensed and/or fragmented nuclei (Majno and Joris 1995). Four types of morphological change of the nucleus were here considered: (i) reduction of the nuclear volume (pyknosis), (ii) nuclear fragmentation (karyorrhexis), (iii) vacuolated cytoplasm and nucleus displaced to a peripheral position, and (iv) chromatin dispersion (karyolysis) (Kroemer et al. 2009). Genotoxic effects were quantified by micronuclei and chromosomal aberrations, such as C-metaphases, multipolar anaphases and telophases, chromosome adherences, chromosome bridges, polyploidy, bi-nucleated cells, and chromosome losses and breaks. Mutagenicity was quantified by micronuclei and chromosome breaks.

Data analysis

Interphase, mitotic, cellular death, micronuclei, and chromosomal aberrations indexes were normalized by calculating the number of cells in each category if exactly 500 cells would have been observed per slide. These indexes are the proportion of cells in each category relatively to the total number of intact cells (500).

Root length values were log transformed and proportional data were arcsine transformed using the Freeman and Tukey modification (Zar 2010). Significant differences against the negative control were checked with one-way ANOVA, followed by the one-tailed Dunnett's multiple comparisons test. A back transformation with correction (Zar 2010) was applied to estimate means of proportional data. Assays were validated through the comparison of the three controls using a one-way ANOVA. The software STATISTICA 8.0 was used.

\section{Results}

The germination rate per Petri plate ranged between 64 and $99 \%$ with no significant differences among treatments $(p=0.209)$ (Fig. 1). The 10 and $100 \%$ AMD reduced root growth $(p<0.0001)$ (Fig. 2). Interphase, mitotic, chromosomal aberrations, and cellular death indexes were significantly altered by AMD dilutions (Fig. 3). The $0.1 \%$ AMD presented significantly less cells in mitosis and more cells with chromosomal aberrations than the negative control (Fig. 3). The undiluted AMD showed a comparatively low number of chromosomal aberrations, which was due to the very low number of live cells in mitosis and interphase (Fig. 3). Results on chromosomal aberrations, nuclear abnormalities and cellular death types are shown in Table 2. The frequency of multipolarity, C-metaphase and adherence after the exposure to $1 \%$ AMD was significantly higher than in the negative control; adherence being

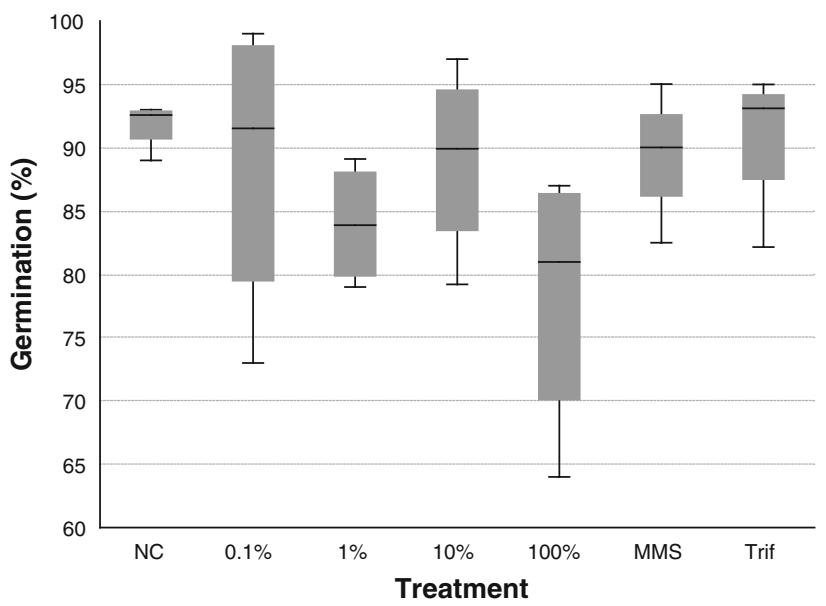

Fig. 1 Box-and-whiskers plot of the Allium cepa seed germination index after an exposure to $100,10,1$, and $0.1 \%$ acid mine drainage. The abbreviations NC, MMS and Trif indicate the negative control and the positive controls with methyl methanesulfonate and trifluralin, respectively 


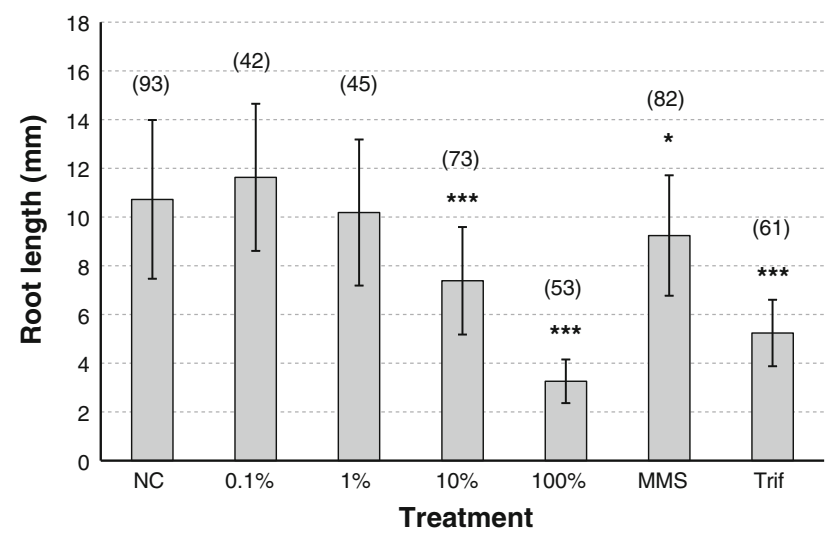

Fig. 2 Mean and SD of Allium cepa root length (in $\mathrm{mm}$ ) after an exposure to $100,10,1$, and $0.1 \%$ acid mine drainage. The abbreviations $N C, M M S$ and Trif indicate the negative control and the positive controls with methyl methanesulfonate and trifluralin, respectively. Sample size is indicated inside brackets. Asterisks indicate significant differences relatively to the negative control $(* p \leq 0.05 ; * * p \leq 0.001 ; * * * p \leq 0.0001)$

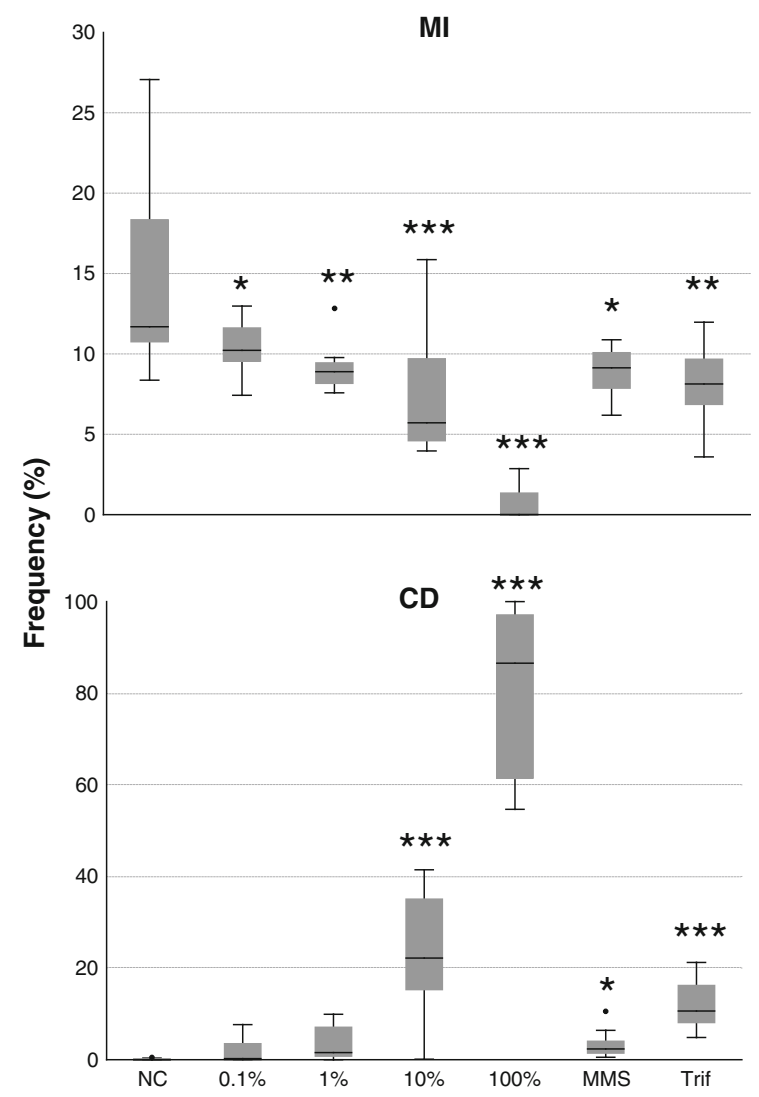

Treatment

Fig. 3 Box-and-whiskers plots of mitotic (MI), interphase (Int), cellular death (CD), and chromosomal aberrations (CA) indexes indexes of Allium cepa root meristematic cells after an exposure to $100,10,1$, and $0.1 \%$ acid mine drainage. The abbreviations $N C$, $M M S$ and Trif indicate the negative control and the positive controls also significantly higher in the $0.1 \%$ AMD. Mutagenicity was found for $0.1 \%$ AMD (Fig. 4).

After 24 and $48 \mathrm{~h}$ of recovery, in the absence of contaminants, cytotoxic and genotoxic effects of AMD on the meristematic cells were still present (Fig. 5). Among the interphase, mitotic, chromosomal aberrations, and cellular death indexes, only the former revealed a recovery. Worth noting is that the significantly higher amount of cells with chromosomal aberrations in the $0.1 \%$ AMD, relatively to the negative control, persisted throughout the recovery period of $48 \mathrm{~h}$. Mutagenicity was reduced when ended the exposure to AMD, with AMD dilutions loosing their effects at $24 \mathrm{~h}$ of recovery and the undiluted AMD at $48 \mathrm{~h}$ (Fig. 6).

\section{Discussion}

Due to the extreme acidity of undiluted AMD ( $\mathrm{pH} 1.8$ ), a significant inhibition of germination was expectable as
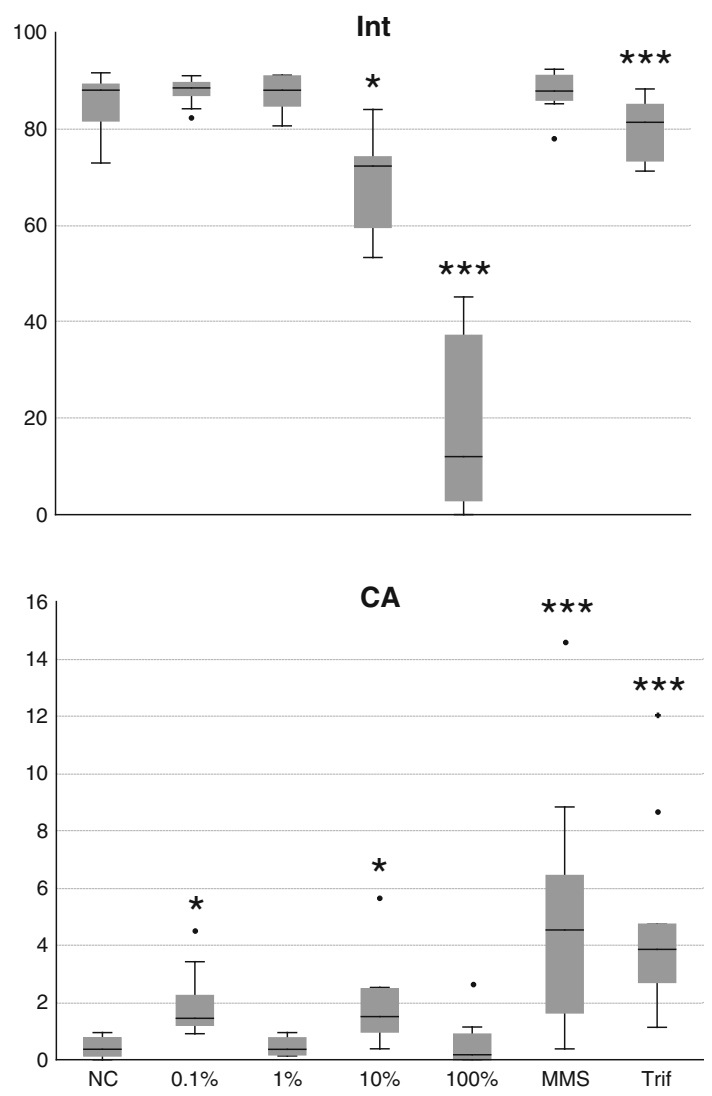

with methyl methanesulfonate and trifluralin, respectively. Asterisks indicate significant differences relatively to the negative control $(* p \leq 0.05 ; * * p \leq 0.001 ; * * * p \leq 0.0001)$. Outliers are represented by black dots 
Table 2 Back transformed means and coefficients of variation of arcsin transformed values (in \%, inside brackets) of frequencies of chromosomal aberrations, nuclear abnormalities and cellular death

types in Allium cepa root meristematic cells after an exposure to 100 , 10,1 , and $0.1 \%$ acid mine drainage

\begin{tabular}{llllllllllllllll}
\hline & NC & & $0.1 \%$ & AMD & $1 \%$ AMD & $10 \%$ AMD & $100 \%$ AMD & MMS & Trif \\
\hline Micronuclei & 0.128 & $(3)$ & 0.428 & $(3)$ & 0.376 & $(5)$ & 0.879 & $(6)$ & 2.150 & $(12)^{*}$ & 4.122 & $(8)^{*}$ & 2.017 & $(7)^{*}$ \\
Chromosomal break & 0.021 & $(1)$ & 0.027 & $(2)$ & 0.020 & $(1)$ & 0.020 & $(1)$ & 0.063 & $(2)$ & 0.139 & $(3)^{*}$ & 0.000 & $(0)$ \\
Chromosomal loss & 0.021 & $(1)$ & 0.052 & $(2)$ & 0.042 & $(2)$ & 0.059 & $(2)$ & 0.000 & $(0)$ & 0.133 & $(2)^{*}$ & 0.076 & $(2)$ \\
Chromosomal bridge & 0.000 & $(0)$ & 0.017 & $(1)$ & 0.060 & $(2)$ & 0.120 & $(3)^{*}$ & 0.000 & $(0)$ & 0.040 & $(2)$ & 0.075 & $(2)^{*}$ \\
C-metaphase & 0.000 & $(0)$ & 0.051 & $(2)$ & 0.115 & $(3) *$ & 0.020 & $(1)$ & 0.000 & $(0)$ & 0.000 & $(0)$ & 0.593 & $(6)^{*}$ \\
Adherence & 0.192 & $(3)$ & 0.911 & $(2)^{*}$ & 0.882 & $(3) *$ & 0.561 & $(3)^{*}$ & 0.049 & $(2)$ & 0.403 & $(4)$ & 0.301 & $(3)$ \\
Multipolarity & 0.020 & $(1)$ & 0.118 & $(3)$ & 0.256 & $(2)^{*}$ & 0.235 & $(4)$ & 0.020 & $(1)$ & 0.061 & $(2)$ & 0.300 & $(3)^{*}$ \\
Laggard & 0.000 & $(0)$ & 0.030 & $(2)$ & 0.028 & $(2)$ & 0.036 & $(2)$ & 0.000 & $(0)$ & 0.041 & $(2)$ & 0.076 & $(2)^{*}$ \\
Nuclear buds & 0.108 & $(3)$ & 0.010 & $(1)$ & 0.114 & $(3)$ & 0.066 & $(2)$ & 0.063 & $(2)$ & 0.136 & $(3)$ & 0.555 & $(3)^{*}$ \\
Lobulated nuclei & 0.000 & $(0)$ & 0.000 & $(0)$ & 0.000 & $(0)$ & 0.000 & $(0)$ & 0.000 & $(0)$ & 0.000 & $(0)$ & 0.828 & $(4)^{*}$ \\
Polynucleated cell & 0.000 & $(0)$ & 0.000 & $(0)$ & 0.000 & $(0)$ & 0.000 & $(0)$ & 0.000 & $(0)$ & 0.000 & $(0)$ & 0.057 & $(2)^{*}$ \\
Cellular death & & & & & & & & & & & & & \\
Peripherical nuclei & 0.000 & $(0)$ & 0.196 & $(4)$ & 0.050 & $(2)$ & 0.734 & $(7)$ & 3.980 & $(10)^{*}$ & 0.114 & $(3)$ & 0.170 & $(3)^{*}$ \\
Karyolysis & 0.000 & $(0)$ & 0.032 & $(2)$ & 0.029 & $(2)$ & 0.000 & $(0)$ & 0.617 & $(6)^{*}$ & 0.821 & $(8)$ & 1.847 & $(7)^{*}$ \\
Pyknosis & 0.057 & $(2)$ & 0.861 & $(8)$ & 1.971 & $(10)$ & 6.681 & $(11)^{*}$ & 33.91 & $(21)^{*}$ & 1.288 & $(6)^{*}$ & 3.702 & $(7)^{*}$ \\
Karyorrhexis & 0.082 & $(3)$ & 0.263 & $(4)$ & 1.545 & $(8)$ & 16.35 & $(14)^{*}$ & 34.17 & $(23)^{*}$ & 1.338 & $(8)$ & 6.471 & $(13)^{*}$
\end{tabular}

The abbreviations NC, MMS and Trif indicate the negative control and the positive controls with methyl methanesulfonate and trifluralin, respectively

* Value significantly larger than the negative control $(p<0.05)$

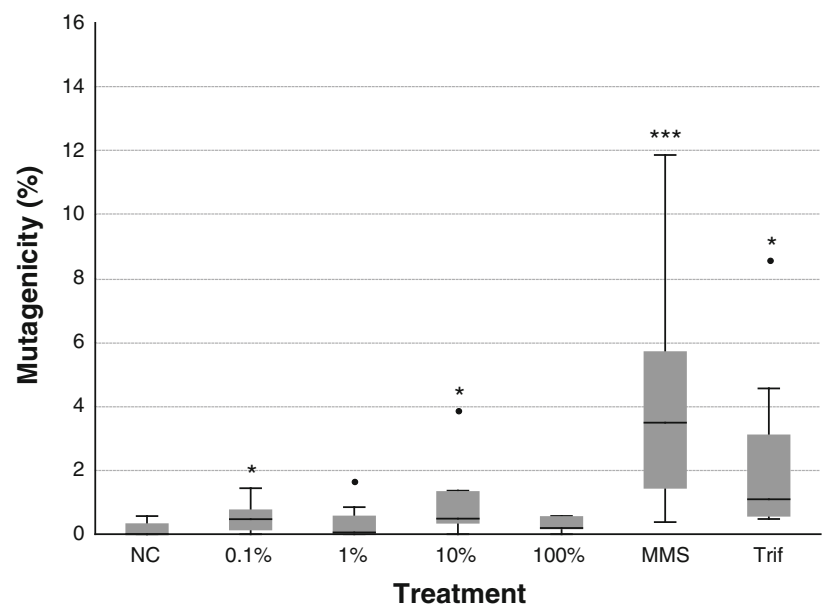

Fig. 4 Box-and-whiskers plot of the mutagenic index of Allium cepa root meristematic cells after an exposure to $100,10,1$, and $0.1 \%$ acid mine drainage. The abbreviations $N C, M M S$ and Trif indicate the negative control and the positive controls with methyl methanesulfonate and trifluralin, respectively. Asterisks indicate significant differences relatively to the negative control $(* p \leq 0.05$; $* * p \leq 0.001 ; * * * p \leq 0.0001)$. Outliers are represented by black dots

reported by other works studying the process of seed germination under acidic conditions. For instance, Salter and McIlvaine (1920) promoted the germination of wheat, corn, soybean, red clover, and alfalfa in culture media with $\mathrm{pH}$ ranging from 2 to 7.5 and found that germination occurred at $\mathrm{pH} 3$, but at $\mathrm{pH} 2$, although the germination process started (swelling of the seeds), only two species had germination rates above $50 \%$ and all seedlings were dead after 7 days. Turner et al. (1988) exposed Paulownia tomentosa seeds to $\mathrm{pH}$ between 1.5 and 7.0, to address the possibility to colonize affected soil in charcoal mines and verified that no sprout take place below $\mathrm{pH} 4$. Shoemaker and Carlson (1990) only obtained normal levels of germination at $\mathrm{pH} 5$ when using a filter paper culture. Passiflora alata seeds showed higher germination rates and initial normal development at pH 3 (Wagner Jr. et al. 2006). Pinus contorta and Picea glauca seeds presented normal germination rates at $\mathrm{pH} 2.2$ (Redmann and Abouguendia 1979). Germination occurrence does not imply that the remaining steps of root development may proceed without interference of acidity, as germination and development are two different processes (Bewley 1997). During root growth, energetic resources stored in the seed are used and molecular and physiological processes (DNA synthesis, protein, cell division) are activated, so growth is affected by mode of action and/or intensity of stressors over those processes (Cho et al. 2003; John et al. 2009). Root growth assays have been considered a good indicator for metal sensitivity since their design in 1957 by Wilkins (Baker 1987). Growth was inhibited at the two highest AMD concentrations, agreeing with other studies where seeds of A. сера (Fiskesjö 1985; Lerda 1992) and other plant species were exposed to metals that are present in the AMD effluent (Wong and Bradshaw 1982; Symeonidis and 


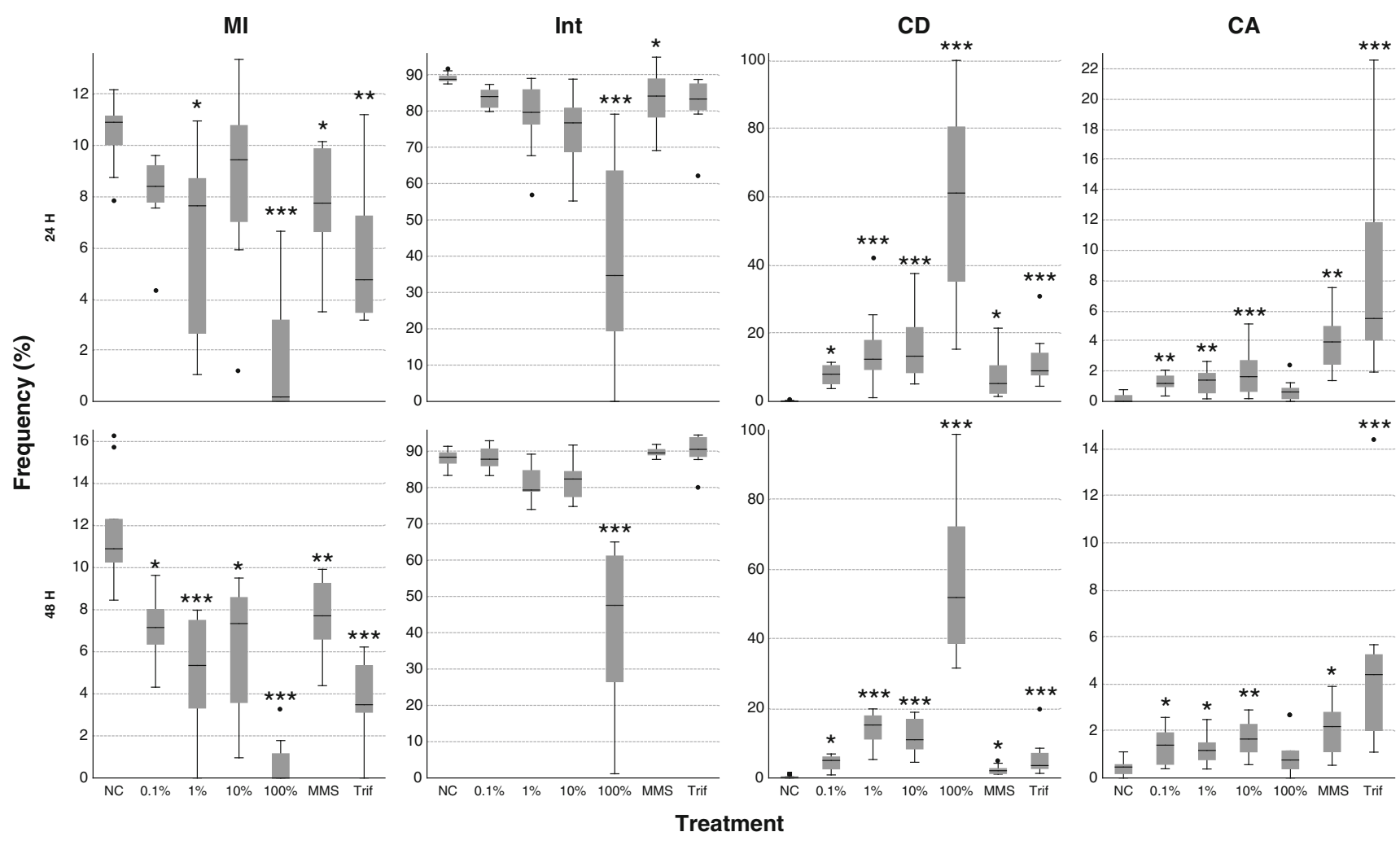

Fig. 5 Box-and-whiskers plots of mitotic (MI), interphase (Int), cellular death (CD), and chromosomal aberrations (CA) indexes of Allium cepa root meristematic cells at 24 and $48 \mathrm{~h}$ of recovery after an exposure to $100,10,1$, and $0.1 \%$ acid mine drainage. The abbreviations $N C, M M S$ and Trif indicate the negative control and the positive controls with methyl methanesulfonate and trifluralin, respectively. Asterisks indicate significant differences relatively to the negative control (* $p \leq 0.05$; ** $p \leq 0.001$; *** $p \leq 0.0001$ ). Outliers are represented by black dots
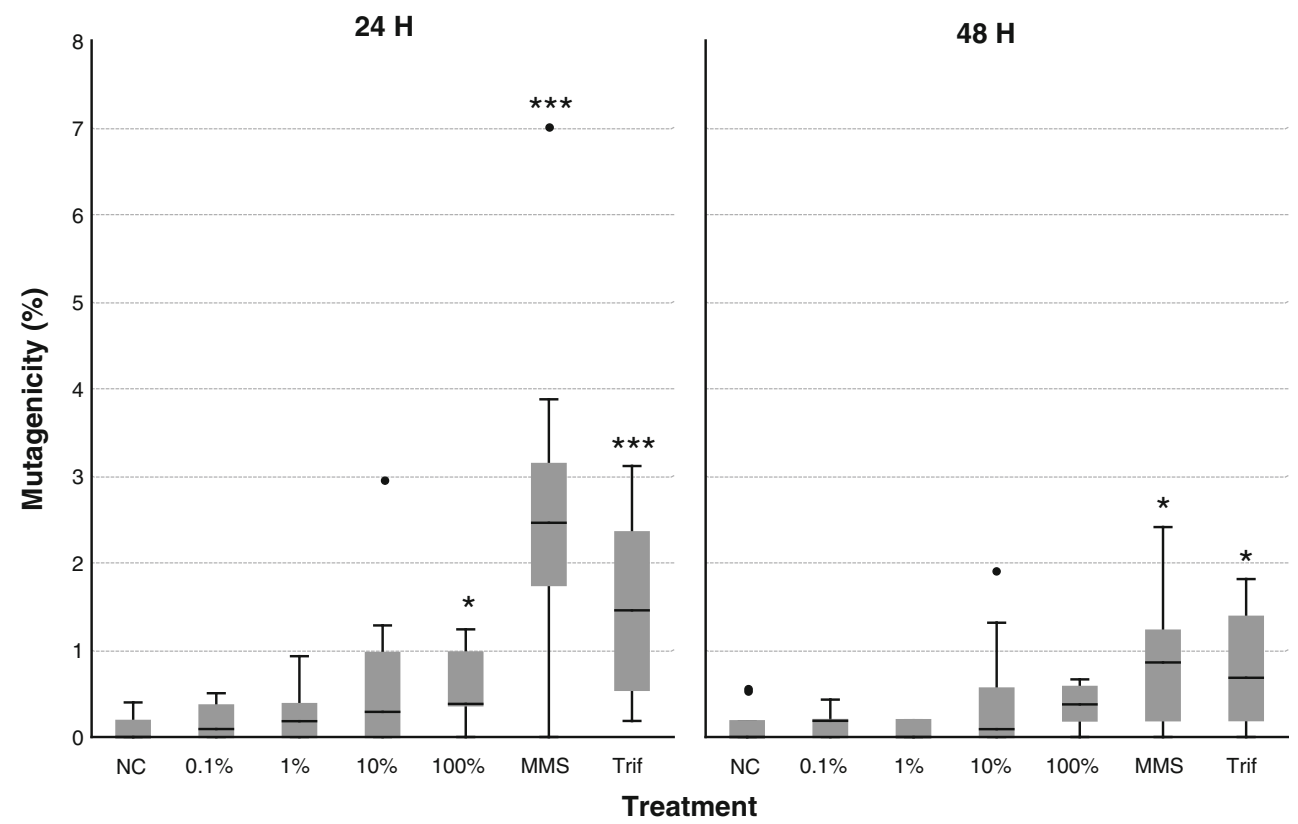

Fig. 6 Box-and-whiskers plot of the mutagenic index of Allium cepa root meristematic cells at 24 and $48 \mathrm{~h}$ of recovery after an exposure to $100,10,1$, and $0.1 \%$ acid mine drainage. The abbreviations $N C$, $M M S$ and Trif indicate the negative control and the positive controls

with methyl methanesulfonate and trifluralin, respectively. Asterisks indicate significant differences relatively to the negative control (* $p \leq 0.05$; ** $p \leq 0.001$; *** $p \leq 0.0001)$. Outliers are represented by black dots 
Karataglis 1992; Lin et al. 2003; Liu et al. 2007; Aydinalp and Marinova 2009; Soudek et al. 2011).

Alterations in the mitotic index have been considered good evaluators of cytotoxic effects of environmental contaminants (Smaka-Kincl et al. 1996; Fernandes et al. 2007; Caritá and Marin-Morales 2008; Leme et al. 2008). Cell division only completes the cycle if all signaling pathways are functional. If chemical requirements are disrupted (e.g. the production of cyclins regulators of G1 phase to $\mathrm{S}$ phase and $\mathrm{G} 2$ to mitosis; activation of cyclindependent protein kinases), cell division check-points are not transposed, and the process is discontinued. Significant decreases in the mitotic index mean that external factors had interfered with the cell division process. In the present study, even the lowest AMD concentration acted as a stressor at the cellular level. According to Patra et al. (2004), metals, mainly from groups IV and VII, have implications on the mitotic index $(\mathrm{Cd}, \mathrm{Cu}, \mathrm{Hg}, \mathrm{Cr}, \mathrm{Co}, \mathrm{Ni}$, $\mathrm{Be}>\mathrm{Zn}, \mathrm{Al}, \mathrm{Mn}, \mathrm{Fe}, \mathrm{Se}, \mathrm{Sr}, \mathrm{Sb}, \mathrm{Ca}, \mathrm{Ti}, \mathrm{Mg}>\mathrm{V}$, As, Mo, $\mathrm{Ba}, \mathrm{Pb}$ ) and this AMD have at least 4 metals belonging to the strongest effectors group $(\mathrm{Cu}, \mathrm{Ni}, \mathrm{Cd}$, and $\mathrm{Cr})$.

Cell death is also an endpoint for cytotoxicity. Death is induced when a contaminant promotes permanent damages in DNA molecules and/or when some other cell processes occur, such as changes in enzyme activity, osmotic deregulation and loss of membrane integrity. Cell death can be identified by morphological alterations of the nucleus and/or cell (Kroemer et al. 2009). Among the morphological changes of the nucleus leading to cell death, AMD induced pyknosis and karyorrhexis with a doseresponse pattern.

The presence of chromosomal aberrations provides a measure of genotoxicity. They allow the discrimination between clastogenic and aneugenic effects (Leme and Marin-Morales 2009), and contribute to understand the cell death process and effects persistence after exposure to contaminants (Fernandes et al. 2009; Leme and MarinMorales 2009). Even with $0.1 \%$ AMD, an increased frequency of chromosomal aberrations occurred. Only at the undiluted AMD, no significant differences were found, but this was most probably due to the low number of live cells and consequent reduction in the relative occurrence of chromosomal aberrations.

Chromosomal adherences were observed in all AMD dilutions, occurring mainly during metaphase with some chromosomal compression on the equatorial plate (not complete compression). Chromosomal abnormalities induced by AMD included also micronuclei and multipolar anaphases and telophases. Adherences and multipolarity are considered aneugenic effects, while micronuclei can be clastogenic or aneugenic, depending if they are originated by chromosomal breaks or losses of whole chromosomes, respectively (Fernandes et al. 2007). In the present study, the frequency of chromosomal breaks and chromosomal losses was similar, such as bridges and C-metaphases, disallowing a clear categorization of AMD as clastogenic or aneugenic. Chromosomal losses are not considered as mutagenic effects. First, because if nuclei lose a whole chromosome, cell will be unviable and death process will begin. Second, because those chromosomes can return to nuclei, which is the case of synchronous micronuclei (Huang et al. 2012). These micronuclei will respond to the cell signaling as the main nuclei and during the cell division process they will be incorporated again (Gustavino et al. 2001). Chromosomal breaks and asynchronous micronuclei are the chromosomal aberrations used to evaluate mutagenicity. The significant occurrence of micronuclei and chromosomal breaks combined revealed AMD to be mutagenic even at a $0.1 \%$ concentration. At the highest AMD concentrations, the reduced number of live cells masked possible dose-response trends which were undetected in most chromosomal aberrations.

Recovery assays revealed the so-called "cell cycle delay", which leads to late cell responses; even though cells are no longer subjected to direct toxic exposure, they continue to express genotoxic effects (Kirkland 1998; Komissarova et al. 2005). Longer recovery periods would be needed to quantify the temporal extension of AMD genotoxic effects (Aaron et al. 1995; Kirkland 1998; HERAG 2007).

In conclusion, data gathered in the present study revealed the AMD effluent of the abandoned São Domingos mine to be mutagenic and genotoxic, even after diluting it to 1 and $0.1 \%$. Although transferability of these laboratory results to the complex field scenario is not straightforward, dilutions within this range were previously found to be below the lethality threshold and to elicit sublethal effects on reproduction of locally collected $D$. longispina clonal lineages (Lopes et al., 2005; Martins et al., 2007; Saro et al., 2012). Therefore, when using neutral markers, as Martins et al. (2009) and Silva et al. (2010) did, a possible overestimation and/or increase in genetic diversity due to mutations cannot be ruled out.

Acknowledgments This study was partially was funded by FSE and $\mathrm{POPH}$ by national funds through Fundação para a Ciência e a Tecnologia and Ministério da Ciência, Tecnologia e Ensino Superior (Ph.D. Grant SFRH/BD/28526/2006 to Olímpia Sobral).

\section{References}

Aaron CS, Yu RL, Bacon JA, Kirkland D, McEnaney S, Marshall R (1995) Comparative mutagenicity testing of ceftiofur sodium II. Cytogenitic damage induced in vitro by ceftiofur is reversible and is due to cell cycle delay. Mutat Res-Genet Toxicol Environ 345:37-47 Agra AR, Guilhermino L, Soares AM, Barata C (2010) Genetic costs of tolerance to metals in Daphnia longispina populations 
historically exposed to a copper mine drainage. Environ Toxicol Chem 29:939-946

Agra AR, Soares AMVM, Barata C (2011) Life-history consequences of adaptation to pollution. Daphnia longispina clones historically exposed to copper? Ecotoxicology 20:552-562

Au WW, Cantelli -Forti G, Hrelia P, Legator MS (1990) Cytogenetic assays in genotoxic studies: somatic cell effects of benzene and germinal cell effects of dibromochloropropane. Teratogen Carcin Mutagen 10:125-134

Aydinalp C, Marinova S (2009) The effects of heavy metals on seed germination and plant growth on alfalfa plant (Medicago sativa). Bulg J Agric Sci 15:347-350

Baker AJM (1987) Metal tolerance. New Phytol 106:93-111

Bewley JD (1997) Seed germination and dormancy. Plant Cell 9:1055-1066

Caritá R, Marin-Morales MA (2008) Induction of chromosome aberrations in the Allium cepa test system caused by the exposure of seeds to industrial effluents contaminated with azo dyes. Chemosphere 72:722-725

Chauhan LKS, Saxena PN, Gupta SK (1999) Cytogenetic effects of cypermethrin and fenvalerate on the root meristem cells of Allium cepa. Environ Exp Bot 42:181-189

Cho M, Chardonnens AN, Dietz K-J (2003) Differential heavy metal tolerance of Arabidopsis halleri and Arabidopsis thaliana: a leaf slice test. New Phytol 158:287-293

De Bisthoven LJ, Gerhardt A, Soares AMVM (2004) Effects of acid mine drainage on larval Chironomus (Diptera, Chironomidae) measured with the multispecies freshwater Biomonitor ${ }^{\circledR}$. Environ Toxicol Chem 23:1123-1128

Dearfield KL, Cimino MC, McCarroll NE, Mauer I, Valcovic LR (2002) Genotoxicity risk assessment: a proposed classification strategy. Mutat Res-Gen Toxicol Environ 521:121-135

Fernandes TCC, Mazzeo DEC, Marin-Morales MA (2007) Mechanism of micronuclei formation in polyploidizated cells of Allium cepa exposed to trifluralin herbicide. Pestic Biochem Physiol $88: 252-259$

Fernandes TCC, Mazzeo DEC, Marin-Morales MA (2009) Origin of nuclear and chromosomal alterations derived from the action of an aneugenic agent-Trifluralin herbicide. Ecotoxicol Environ Saf 72:1680-1686

Fiskesjö G (1985) The Allium test as a standard in environmental monitoring. Hereditas 102:99-112

Fiskesjö G (1993) The Allium test in wastewater monitoring. Environ Toxicol Water 8:291-298

Gerhardt A, Janssens de Bisthoven L, Soares AMVM (2005) Effects of acid mine drainage and acidity on the activity of Choroterpes picteti (Ephemeroptera: leptophlebiidae). Arch Environ Contam Toxicol 48:450-458

Grant WF (1994) The present status of higher plant bioassays for the detection of environmental mutagens. Mutat Res-Fund Mol Mech 310:175-185

Grant WF (1998) Higher plant assays for the detection of genotoxicity in air polluted environments. Ecosyst Health 4:210-229

Grant WF (1999) Higher plant assays for the detection of chromosomal aberrations and gene mutations: a brief historical background on their use for screening and monitoring environmental chemicals. Mutat Res-Fund Mol M 426:107-112

Gustavino B, Scornajenghi KA, Minissi S, Ciccotti E (2001) Micronuclei induced in erythrocytes of Cyprinus carpio (Teleostei, Pisces) by X-rays and colchicine. Mutat Res-Gen Tox Env 494:151-159

Heddle JA, Cimino MC, Hayashi M, Romagna F, Shelby MD, Tucker JD, Vanparys P, MacGregor JT (1991) Micronuclei as an index of cytogenetic damage: past, present, and future. Environ Mol Mutagen 18:277-291
HERAG (2007) Mutagenicity. Health Risk Assessment Guidance For Metals Fact Sheet 05

Houk VS (1992) The genotoxicity of industrial wastes and effluents: a review. Mutat Res-Rev Genet 277:91-138

Huang Y, Jiang L, Yi Q, Lv L, Wang Z, Zhao X, Zhong L, Jiang H, Rasool S, Hao Q, Guo Z, Cooke HJ, Fenech M, Shi Q (2012) Lagging chromosomes entrapped in micronuclei are not 'lost' by cells. Cell Res 22:932-935

John R, Ahmad P, Gadgil K, Sharma S (2009) Heavy metal toxicity: effect on plant growth, biochemical parameters and metal accumulation by Brassica juncea L. Int J Plant Prod 3:65-76

Kirkland D (1998) Chromosome aberration testing in genetic toxicology: past, present and future. Mutat Res-Fund Mol Mech 404:173-185

Komissarova EV, Saha SK, Rossman TG (2005) Dead or dying: the importance of time in cytotoxicity assays using arsenite as an example. Toxicol Appl Pharm 202:99-107

Kroemer G, Galluzzi L, Vandenabeele P, Abrams J, Alnemri E, Baehrecke E, Blagosklonny M, El-Deiry W, Golstein P, Green D, Hengartner M, Knight R, Kumar S, Lipton S, Malorni W, Nuñez G, Peter M, Tschopp J, Yuan J, Piacentini M, Zhivotovsky B, Melino G (2009) Classification of cell death: recommendations of the Nomenclature Committee on Cell Death 2009. Cell Death Differ 16:3-11

Leme DM, Marin-Morales MA (2009) Allium cepa test in environmental monitoring: a review on its application. Mutat Res-Rev Mutat 682:71-81

Leme DM, Angelis DdFd, Marin-Morales MA (2008) Action mechanisms of petroleum hydrocarbons present in waters impacted by an oil spill on the genetic material of Allium cepa root cells. Aquat Toxicol 88:214-219

Lerda D (1992) The effect of lead on Allium cepa L. Mutat Res Lett 281:89-92

Lin J, Jiang W, Liu D (2003) Accumulation of copper by roots, hypocotyls, cotyledons and leaves of sunflower (Helianthus annuus L.). Bioresource Technol 86:151-155

Liu C, Shen Z, Li X (2007) Accumulation and detoxification of cadmium in Brassica pekinensis and B. chinensis. Biol Plantarum 51:116-120

Lopes I, Gonçalves F, Soares AMVM, Ribeiro R (1999) Discriminating the ecotoxicity due to metals and to low $\mathrm{pH}$ in acid mine drainage. Ecotoxicol Environ Saf 44:207-214

Lopes I, Baird DJ, Ribeiro R (2005) Resistance to metal contamination by historically-stressed populations of Ceriodaphnia pulchella: environmental influence versus genetic determination. Chemosphere 61:1189-1197

Ma T-H, Cabrera Guillermo L, Owens E (2005) Genotoxic agents detected by plant bioassays. Rev Environ Health 20:1-13

Majno G, Joris I (1995) Apoptosis, oncosis, and necrosis. An overview of cell death. Am J Pathol 146:3-15

Martins N, Lopes I, Guilhermino L, Bebianno MJ, Ribeiro R (2005) Lack of evidence for metallothionein role in tolerance to copper by natural populations of Daphnia longispina. Bull Environ Contam Toxicol 74:761-768

Martins N, Lopes I, Harper RM, Ross P, Ribeiro R (2007) Differential resistance to copper and mine drainage in Daphnia longispina: relationship with allozyme genotypes. Environ Toxicol Chem 26:1904-1909

Martins N, Bollinger C, Harper RM, Ribeiro R (2009) Effects of acid mine drainage on the genetic diversity and structure of a natural population of Daphnia longispina. Aquat Toxicol 92:104-112

Mazzeo DEC, Fernandes TCC, Marin-Morales MA (2011) Cellular damages in the Allium cepa test system, caused by BTEX mixture prior and after biodegradation process. Chemosphere 85:13-18 
Moreira-Santos M, Soares AMVM, Ribeiro R (2004) An in situ bioassay for freshwater environments with the microalga Pseudokirchneriella subcapitata. Ecotoxicol Environ Saf 59:164-173

Moreira-Santos M, Donato C, Lopes I, Ribeiro R (2008) Avoidance tests with small fish: determination of the median avoidance concentration and of the lowest-observed-effect gradient. Environ Toxicol Chem 27:1576-1582

Patra M, Sharma A (2002) Relative efficacy of Allium cepa and Allium sativum in anaphase-telophase test screening metal genotoxicity. Biologia 57:409-414

Patra M, Bhowmik N, Bandopadhyay B, Sharma A (2004) Comparison of mercury, lead and arsenic with respect to genotoxic effects on plant systems and the development of genetic tolerance. Environ Exp Bot 52:199-223

Pereira EG, Moura I, Costa JR, Mahony JD, Thomann RV (1995) The S. Domingos Mine: a study of heavy metal contamination in the water column and sediments of the Chança River Basin by discharge from an ancient cupriferous pyrite mine (Portugal). Mar Freshwater Res 46:145-151

Pereira AMM, Soares AMVM, Gonçalves F, Ribeiro R (2000) Watercolumn, sediment, and in situ chronic bioassays with cladocerans. Ecotoxicol Environ Saf 47:27-38

Pérez-Cadahía B, Laffon B, Porta M, Lafuente A, Cabaleiro T, López T, Caride A, Pumarega J, Romero A, Pásaro E, Méndez J (2008) Relationship between blood concentrations of heavy metals and cytogenetic and endocrine parameters among subjects involved in cleaning coastal areas affected by the 'Prestige' tanker oil spill. Chemosphere 71:447-455

Pfrender ME, Spitze K, Hicks J, Morgan K, Latta L, Lynch M (2000) Lack of concordance between genetic diversity estimates at the molecular and quantitative-trait levels. Conserv Genet 1:263-269

Rank J, Nielsen MH (1993) A modified Allium test as a tool in the screening of the genotoxicity of complex mixtures. Hereditas 118:49-53

Redmann RE, Abouguendia ZM (1979) Germination and seedling growth on substrates with extreme $\mathrm{pH}$-Laboratory evaluation of buffers. J Appl Ecol 16:901-907

Ribeiro R, Lopes I (2013) Contaminant driven genetic erosion and associated hypotheses on alleles loss, reduced population growth rate and increased susceptibility to future stressors: an essay. Ecotoxicology 22 (in press). doi: 10.1007/s10646-013-1070-0

Ribeiro R, Baird DJ, Soares AMVM, Lopes I (2012) Contaminant driven genetic erosion: a case study with Daphnia longispina. Environ Toxicol Chem 31:977-982
Salter RM, McIlvaine TC (1920) Effect of reaction of solution on germination of seeds and on growth of seedlings. J Agr Res 19:73-95

Saro L, Lopes I, Martins N, Ribeiro R (2012) Testing hypotheses on the resistance to metals by Daphnia longispina: differential acclimation, endpoints association, and fitness costs. Environ Toxicol Chem 31:909-915

Shoemaker CA, Carlson WH (1990) pH affects seed germination of eight bedding plant species. HortScience 25:762-764

Silva RM, Pereira F, Carneiro J, Sobral O, Ribeiro R, Amorim A, Soares AMVM, Lopes I (2010) Microevolution in a natural population of Daphnia longispina exposed to acid mine drainage. In: N. Hamamura SS, S. Mendo, C. M. Barroso, H. Iwata and S. Tanabe (ed) Interdisciplinary studies on environmental chemistry-biological responses to contaminants, Terrapub, Tokyo, p 213-218

Smaka-Kincl V, Stegnar P, Lovka M, Toman MJ (1996) The evaluation of waste, surface and ground water quality using the Allium test procedure. Mutat Res-Genet Toxicol 368:171-179

Soudek P, Petrová S , Vaněk T (2011) Heavy metal uptake and stress responses of hydroponically cultivated garlic (Allium sativum L.). Environ Exp Bot 74:289-295

Symeonidis L, Karataglis S (1992) Interactive effects of cadmium, lead and zinc on root growth of two metal tolerant genotypes Holcus lanatus L. Biometals 5:173-178

Turner GD, Lau RR, Young DR (1988) Effect of acidity on germination and seedling growth of Paulownia tomentosa. J Appl Ecol 25:561-567

Ulsh BA, Miller SM, Mallory FF, Mitchel REJ, Morrison DP, Boreham DR (2004) Cytogenetic dose-response and adaptive response in cells of ungulate species exposed to ionizing radiation. J Environ Radioactiv 74:73-81

Wagner A Jr, Santos CEM, Costa e Silva JO, Sobreira AR, Negreiros JRS (2006) Influence of soaking water $\mathrm{pH}$ and substrates in the seeds germination and initial development of the sweet passion fruit. R Bras Agrociência, Pelotas 12:231-235

Whysner J, Vijayaraj Reddy M, Ross PM, Mohan M, Lax EA (2004) Genotoxicity of benzene and its metabolites. Mutat Res-Rev Mutat 566:99-130

Wong MH, Bradshaw AD (1982) A comparison of the toxicity of heavy metals, using root elongation of rye grass, Lolium perenne. New Phytol 91:255-261

Zar JH (2010) Biostatistical analysis. Pearson Prentice-Hall, Upper Saddle River, NJ 